\title{
THE ROLE OF TEACHERS IN IMPROVING THE DISCIPLINE CHARACTER OF STUDENTS
}

\author{
Subiarto ${ }^{1 *}$, Wakhudin $^{2}$ \\ Universitas Muhammadiyah Purwokerto, INDONESIA
}

Received 30 May 2021 - Revised 26 August 2021 • Accepted 20 September 2021

\begin{abstract}
This study aimed to examine and describe the role of the teacher in improving the character of discipline for students. This research is a descriptive qualitative research. The research subjects were the principal, teachers, and students. The data collection techniques used were interviews, observation, and documentation. Data analysis was performed using qualitative descriptive analysis techniques. The results of this study indicated that the role of teachers in the character building of student discipline at SD Negeri 1 Kendaga is a teacher as an educator, a teacher as ainstructor, a teacher as a guide, a teacher as a trainer, and a teacher as an evaluator. The teacher's efforts in shaping student character are by using the method of habituation, exemplary, lectures and simulations. This research is useful for teachers, to be able to act as good role models, to provide guidance and supervision to improve students discipline.
\end{abstract}

Keywords: Teacher's role, character education, discipline

\section{INTRODUCTION}

Education is very important in human life. Strengthening the character of discipline in education must start early. The success of character education will be the foundation for building the personality of students at the education level above and also in social life in general. For this reason, the role of teachers is currently important in the context of the successful implementation of disciplinary character education. Discipline character is needed so that the school becomes a reliable self-building institution. Through strengthening the character of discipline, it is hoped that a future generation of young generations who are knowledgeable, cultured, moral and civilized will be born in the the globalization era.

The value of disciplined character is very important for humans so that other good character values emerge [1].The importance of strengthening the value of the character of discipline in schools is based on the reason that there are many student behaviors that are contrary to disciplinary norms.

At this time, there were many undisciplined events shown by students. For example, undisciplined behavior includes coming to school not on time, not wearing a complete uniform, cheating, littering, scribbling school walls, skipping school, not doing assignments, and submitting assignments not on time [2].

The decline in the value of character education is very concerning. Given this, character education is very important to be given to students in school, in order to realize educational goals and shape the character of students to become mature individuals. To realize the achievement of the character education program, it is necessary to have the role of teachers in schools to find the right pattern for implementing character education values. One character value that needs to be developed for students is the character of discipline. Discipline is an action that shows orderly behavior and obeys various rules and regulations [3].

The occurrence of undisciplined behavior in schools shows that there have been serious problems in terms of character education, especially the character of discipline. The emergence of undisciplined behavior shows that new discipline is limited to knowledge that does not have a positive impact on changes in student behavior every day [4].There needs to be an innovation so that violations made by students can be handled properly, one of which is through the implementation of the development of disciplined character education for students. The school environment has a strong role in shaping children's character [5].Discipline has three kinds of characteristics, preventive discipline, corrective discipline and progressive discipline [6].

Fostering the disciplinary character of students in schools cannot be separated from the role of the teacher. Teachers must be able to coach student discipline, especially self-discipline. Teachers must be able to help students develop behavior patterns, improve disciplinary character, and implement rules and regulations as a tool to enforce discipline. To discipline students, it is necessary to start with principles that are in accordance with the goals of national education. So that the disciplinary rules need to be guided by this, namely from, by, and for students. while for teachers through the principle of tut wurihandayani or in front of giving an example

(C) 2021 by the authors; licensee PGSD UMP. This article is an open access article distributed under the terms and conditions of the Creative Commons Attribution License (http://creativecommons.org/licenses/by/4.0/).

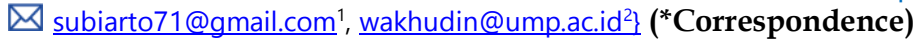


Based on the background of the problems above, the formulation of the problem in this study is what is the role of the teacher in increasing the value of disciplinary character for students? Based on the formulation of the problem above, the objective of the research is to study and describe the role of the teacher in improving the character of discipline for students

\section{METHOD}

This research is a descriptive qualitative research. The research method is a scientific way of obtaining data with specific purposes and uses [7].The data obtained observations, interviews, document analysis, field notes, compiled by researchers at the research location. According to Sukmadinata, explaining descriptive research is a form of research aimed at describing existing phenomena, both natural phenomena and man-made phenomena. This phenomenon can be in the form of forms, activities, characteristics, changes, relationships, similarities, and differences between one phenomenon and another. Based on the definition above, this study provides an overview of the character building of students through the teacher and provides solutions in character-based learning for students in SD Negeri 1 Kendaga.

The research used was qualitative research with descriptive analysis of the case study method. The research subjects were the principal, teachers, and students. Data collection techniques used were interviews, observation, documentation and literature study. Data analysis was performed using qualitative descriptive analysis techniques

\section{RESULT AND DISCUSSION}

A teacher in carrying out his duties must have competence, one of the competences that a teacher must have is social competence, namely competence that emphasizes the teacher so that he can get along with the community, includ communicating with students.

The teacher has a very important role, especially in conveying knowledge and character education, because the teacher's job is not only to teach, but the teacher also educates and directs students to have good behavesand attitudes. The Role of teachers in character building discipline students are teachers as educators, teachers as instructors, teachers as mentors, teachers as trainers, and teachers as role models [8].

The teacher as an educator not only knows about the material to be taught, but he also must have a strong personality that makes him a role model for his students. This is important because as an educator, the teacher not only teaches students to know one kind of thing but the teacher teaches and tells various things. The teacher also has to train the skills, attitudes and mentality of students.

Teachers as educators, namely where teachers become role models for students and their environment [9].The teacher's role as an educator requires a teacher to maintain his authority, be responsible, disciplined, independent, and have a good personality so that he can be an example for his students.

Teachers as instructors, namely teachers carry out their duties in planning and implementing learning in schools. In addition to teaching, teachers must also make efforts to change attitudes, skills, habits, social relationships, appreciation, and so on learning delivered [10]. The teacher as a guide is a teacher who guides or guides students to an attitude that should be done. He is more directed to students' affective rather than cognitive.

The teacher as a trainer is a teacher who can simultaneously be a guide, teacher, educator, motivator and so on. Where the teacher produces a skill or expertise that is taught to students, and is more directed at students' psychomotor.

The role of the teacher as a role model is very important in order to shape the character of the students being taught. Modelingcan be used as the main method in character education [11].In developing disciplined character, exemplary is needed in every educational environment, namely the school, family, and community environment. In the school environment, teacher exemplary is needed in the development of disciplinary character. The teacher's exemplary determines the success of students in the process of having knowledge about character, feelings about character, and actions that reflect character. Teachers who are not disciplined will pass on their indiscipline to their students, so that it will create students who are not disciplined as well.

Character education contains three stages of activity, namely imparting knowledge about character, feelings about character, and actions that reflect character [12]. Judging from the three stages of these activities, it can be seen that character education is actually the same as other types of education, namely that it must touch the three realms of the human psyche, namely the cognitive, affective, and psychomotor domains [13].

Education is expected to take an important part in educating and instilling good character values in students. Character education in the context of education in Indonesia is noble values based on the culture of the Indonesian nation itself to shape and nurture children to become the nation's next generation [14]. However, in reality education today only pays more attention to intellectual aspects rather than emotional and spiritual aspects, so it is not surprising that many of us see deviant behavior from students [15].

The implementation of disciplinary character education can be carried out through several policies, namely 
creating a character education program, establishing school rules and class regulations, carrying dhuhur prayers at school congregation, monitor student disciplinary behavior through daily activity logbooks, involve parents and school committees [16].The character building program for students in schools is realized through intra-curricular and extra-curricular activities. The method of character building students can be done using the method of habituation, exemplary, lectures and simulations [17].

In developing the character of discipline, the role of the teacher also has an important role as the main figure in the school in guiding and educating children. Teachers as parents of children at school. For this reason, the success of children's learning achievement depends on the level of the teacher's ability to create a comfortable climate for the teaching and learning process. for teachers, namely developing their ability to recognize their students more so that lessons are made more precise.

According to Candra, the effective classroom management of teachers should not only be silent but also pay attention and recognize their students [18]. Paying attention to students must also be thorough and fair. The teacher must also understand the characteristics and character of students from various students to be used as a reference in the classroom management process. Insights, discipline, motivation, a comfortable and conducive learning climate, welfare, and school culture are aspects of the success of teachers in teaching and learning activities [19]. Therefore, the teacher's role as a driver in improving the quality of education and shaping children's personalities for the better.

A number of studies have found positive results from implementing character education programs in schools, including higher academic achievement, fewer suspensions and dropouts, and less risky behavior from students [20]. Teacher discipline will have a major influence on the formation of student disciplinary character because teachers become idols and are highly respected by students, therefore teachers should take advantage of the opportunities of the school environment as a place for fostering student disciplinary character. Discipline character is very important for students so that other good character values emerge

Character education is a curriculum developed specifically to teach children about the qualities and traits of good character [21]. In line with the statementis that character education is a national movement to create ethics, responsibility and care by giving example and teach good character through emphasis on universal values [22] .

The role of the teacher as a figure who provides a good role model for children is a must, considering that education does not only convey knowledge, but also educates and guides children's character to be better. So that schools need to convey the development and achievements obtained by children.

The role of teachers who have good performance and have good personalities is in the spotlight of the community as role models for their children in educating and directing children's personalities to be better [23].

Teachers have a role as role models in the implementation of discipline. Teacher role models are very important in determining student discipline because teachers are used as role models and exemplary by their students. Teachers must set an example that is good, honest, fair, and in accordance with their deeds. With a good teacher's example, students' discipline will be good too. If the teacher's role model is not good (less disciplined), students will be less disciplined. Teachers do not expect students to be disciplined well if they lack discipline themselves. Teachers must realize that their behavior will be imitated and imitated by their students, this is what requires teachers to have good discipline so that their students have good discipline as well.

The teacher's role in instilling student discipline is as a role model and motivator [24]. As a role model the teacher provides an example to students and as a motivator the teacher always provides advice to students. Supporting factors in instilling discipline in the form of giving gifts as appreciation and punishment as sanctions that are very instrumental in regulating patterns and behavior of students so that they are always orderly in carrying out discipline.

Thus the role of the teacher is very important in fostering the disciplinary character of students. Therefore, according to Sardiman the teacher is one of the human components in the teaching and learning process, which plays a role in efforts to form potential human resources in the field of development [25]

The role of teachers in carrying out their roles, namely as educators, teaching, leaders, role models, must be able to serve students who are based on optimal awareness, belief, discipline, and responsibility [26]. The teacher as an educator not only knows about the material to be taught, but he also must have a strong personality that makes him a role model for his students. This is important because as an educator, the teacher not only teaches students to know one kind of thing but the teacher teaches and tells various things the teacher must also train the skills, attitudes and mental of the students.

The role of the teacher in the formation of disciplinary character for students at SD Negeri 1 Kendaga, namely: 1) The teacher as an educator, the role of the teacher as an educator, meaning that the teacher is a role model, role model, and a figure who will be identified by students, educating students to become exemplary students, polite and courteous, the teacher educates students to be disciplined in time, and provides a good example so that students themselves are disciplined That teachers are responsible for being models who have moral values and take advantage of opportunities to influence their students. 2) The teacher as a instructor, the role of the teacher as a teacher means that the teacher always teaches with make lesson plans, and design lessons, the teacher teaches the lesson plan is used as a pan duan, teachers also teach how to be disciplined students [27].3) The teacher as a guide, meaning that the role of the teacher guides students to comply with school rules, especially when in the classroom, such as paying attention to the teacher when explaining the lessons that are taking place at SD Negeri 1 Kendaga [28].4) The teacher as a trainer, meaning that the teacher trains students to always do their work, the teacher trains 
students when given homework to do independently, the teacher trains students to always get used to being disciplined both at school and at home, and the teacher trains students to do practice questions [29]. 5) the teacher as an evaluator, gives honest and good assessments, evaluates learning by conducting assessments during the learning process and assessing learning outcomes, the teacher measures the extent to which students understand the lessons that have been given by evaluating the process and learning outcomes, with the evaluating teacher knowing which students can and cannot [30].

In addition, the teacher's goal in the formation of disciplinedcharacter is for the benefit of integral individual growth, disciplinary character education has a long-term goal that is based on the individual contextual active response to the natural social impulses it receives which in turn further sharpens the vision of life to be achieved through a continuous forming process. It was explained that "so that students become successful children and get used to discipline from an early age. In order for students to become disciplined children both at school and at home, implementing or applying a good and orderly life, students become successful students, because forming disciplinecharacters is the basis of all success.

Students are disciplined in disposing of garbage in its place, doing assignments, wearing school uniforms because there is motivation and role models from the teacher [31]. The results of the implementation of education and the inculcation of disciplinary character for students can be seen from the changes in attitudes and behavior experienced by students during their education at SD Negeri 1 Kendaga. It is indeed difficult to identify changes in attitudes and behavior so that it can be said to be a character of noble discipline. discipline towards school regulations, the results of the value of disciplinary character can also be seen from the daily programs that are implemented, so that students are trained to act discipline. This is evidenced by discipline when it comes to school, discipline in doing assignments, and it can be seen from the enthusiasm of students towards programs in fostering the disciplinary character of students, such as $5 S$ habituation (smile, greetings, greetings, courtesy, and courtesy). In its implementation, exemplary is carried out in the process of the activity itself, for example, actions carried out by educators will be easily followed by students. The exemplary method is carried out as a form of giving good examples by educators to students. This method is related to daily activities in the school environment, such as exemplary behavior, telling stories.

After collecting data through observation, interviews, and documentation, it can be analyzed that the teacher's efforts in shaping the character of student discipline at SD Negeri 1 Kendaga are by using several methods, including habituation, exemplary, lectures, discussions, and simulations. Striving for habituation with the storytelling method in teacher learning to insert stories about the importance of character building discipline. Because elementary level students often see or observe the behavior of others. In striving for the formation of disciplinary character, students are accustomed to obeying school regulations so that the character of this discipline is manifested in students.

From the various processes carried out in providing education and inculcating disciplinary character values for students, of course there are goals to be achieved as a result of this implementation. However, not all programs that have been run carried out as expected. But at least, there is a minimal discipline character that students have shown in their daily attitudes and behavior as a form of internalizing the values of disciplinary character in students at SD Negeri 1 Kendaga, this is evidenced by the results of observations and interviews by researchers with studentswhich according to the researcher already reflects disciplinary character activities. Discipline character values that are reflected in students, such as coming to school on time, obeying the rules, throwing garbage in its place, being disciplined in carrying out assignments, reading prayers and shaking hands to the teacher.

\section{CONCLUSION}

The Role of teachers in the character building of student discipline at SD Negeri 1 Kendaga is a teacher as an educator, a teacher as ainstructor, a teacher as a guide, a teacher as a trainer, and a teacher as an evaluator. The role of teachers in SD Negeri 1 Kendaga is very good, because each teacher has implemented the five aspects of the teacher's role properly. The teacher's efforts in shaping student character are by using the method of habituation, exemplary, lectures and simulations. From these methods, graduates from SD Negeri 1 Kendaga that each student must have, namely: discipline that comes from within the individual himself and discipline that comes from outside himself. From the various methods and programs launched at SD Negeri 1 Kendaga, students have seen a change in attitude and behavior that reflects the character of the discipline. This study recommends the teacher, to be able to act as a good role model, to provide guidance and supervision to improve student discipline

\section{REFERENCES}

[1] Hartini, S. (2017). Student Discipline Character Education in the Modern Era of Parent and Teacher Synergy at MTs Negeri Klaten Regency. Al-Asasiyya: Journal Basic Of Education, 2 (1).

[2] Wuryandani, W., Maftuh, B., \& Budimansyah, D. (2014). Discipline Character Education in Elementary Schools. Journal of Cakrawala Pendidikan, 33 (2).

[3] Mustari, M. (2014). Reflection Character Value for Education. Jakarta: Rajawali Press 
[4] Komalasari, K. (2012). The Effect Of Contextual Learning In Civic Education On Students' Character Development. Asia Pacific Journal of Educators and Education, 27 (1), 87-103.

[5] Kristiawan, M. (2015). A Model of Educational Character in High School Al-Istiqamah Simpang Empat, West Pasaman, West Sumatra. Research Journal of Education, 1 (2), 15-20.

[6] Ansori, Y. Z. (2020). Strengthening Student Discipline Character Through the Role of Teachers in Elementary Schools. Jurnal Educatio FKIP UNMA, 6 (1), 177-186.

[7] Sugiyono. (2013). Metode Penelitian Pendidikan Pendekatan Kuantitatif, Kualitatifdan R \& D. Bandung: Alfabeta.

[8] Ramdan, A. Y. Praise YantiFauziah. (2019). The role of parents and teachers in developing character values for elementary school aged children. Premiere Educandum: Journal of Basic Education and Learning, 9 (2) 100 - 111

[9] Mulyasa, E. (2011). Becoming a Professional Teacher: Creating Creative and Fun Learning. Bandung: PT Remaja Rosdakarya.

[10] Hamalik, O. (2009). Teaching and learning process. Jakarta: Earth Literacy

[11] Munawaroh, A.. (2019). Exemplary as a Character Education Method. Journal of Islamic Education Research, 7 (2), 141-155.

[12] Novita, L., Hastuti, D., \& Herawati, T. (2015). Pengaruh iklim keluarga dan keteladanan orang tua terhadap karakter remaja perdesaan. Jurnal Pendidikan Karakter, (2): 184-194.

[13] Park, N., \& Peterson, C. (2006). Moral Competence and Character Strengths among Adolescents: The Development and Validation of the Values in Action Inventory of Strengths for Youth. Journal of Adolescence, 29 (6), 891-909.

[14] Uli, I. (2018). Implementation of character education values in oral literature at IKIP PGRI Pontianak. Journal of Basic Education and Learning, 8 (2), 140-149.

[15] Hardiyana, S. (2014). The Influence of Civics Teachers on Student Character Formation. PPKn Scientific Journal of IKIP Veteran Semarang, 2 (1), 54-64.

[16] Annisa, F. (2018). Planting Of Discipline Character Education Values In Basic School Students. International Journal of Educational Dynamics, 1 (1), 107-114.

[17] Rahmat, N. Sepriadi. Rasmi Daliana. (2017). Character Building of Student Discipline through Class Teachers at SD Negeri 3 Rejosari, East Oku Regency. JMKSP Journal of Management, Leadership, and Education Supervision, 2 (2).

[18] Candra, R. 2015. Classroom Management for Effective Teaching. Journal of International Journal of Education and Psychological Research, 4 (4): 14.

[19] Agustina, P. (2018). Characteristics of Principal Leadership Behavior and School Culture in Primary Schools. Journal of Character Education, 8 (1), 206-219.

[20] Althof W. and Berkowitz M.W. (2012). Moral Education And Character Education: Their Relationship And Roles In Citizenship Education. University of Missouri-St. Louis, USA

[21] Nzekwu, I. (2016). Language Education for Character and Skill Development in Nigeria. International Journal of Arts and Humanitas (IJAH) Bahir Dar-Ethiopia, 5(3), 42-54.

[22] Pala, A. (2011). The Need For Character Education. International Journal Of Social Sciences and Humanity Studies, 3 (2), 23-32.

[23] Palunga, R., \& Marzuki. (2017). The Role of Teachers in Character Development of Students in Junior High School 2 Depok Sleman. Journal of Character Education, 7 (1), 109-123.

[24] Kharisma, C. Suyatno. (2018). The Role of Teachers in Instilling Discipline Characteristics of Students in the Bleber 1 Public Elementary School, Prambanan, Sleman. Basic Education Fundamentals, 1(2), 131-139.

[25] Sardiman, A. M., (2007) Teaching and Learning Interaction and Motivation: Bandung, Rajawali Pers.

[26] Wibowo, I.S., SitiMaqfirotun. (2016). The Role of Teachers in Shaping the Responsibilities of Grade V Elementary School Students. Journal of Basic Education Gentala, 1(1), 61-72.

[27] Interviews with the principal, Mr.Suyitno, S.Pd and interviews with the 6th grade teacher, namely Mrs.Suhartini, S.Pd. SD on May 10, 2021.

[28] Interview with the Religion teacher Mr.Ujang Setiawan, S.Pd.I on May 10, 2021.

[29] Interviews with grade 5 teacher, namely Mrs.Rusmini, S.Pd.SD on May 22, 2021.

[30] Interviews with grade 1 teacher, Mrs. Tri Sulistiyani, S.Pd, SD on May 22, 2021.

[31] Interviews with students,Nurul Alya on May 22, 2021.

\section{http://jurnalnasional.ump/index.php/dinamika}

